\section{Regeneration of Dracaena surculosa Through Indirect Shoot Organogenesis}

Juanxu Liu', Min Deng ${ }^{2}$, Richard J. Henny, and Jianjun Chen ${ }^{3}$

University of Florida, Institute of Food and Agricultural Sciences, Department of Environmental Horticulture and Mid-Florida Research and Education Center, 2725 Binion Road, Apopka, FL 32703

\section{Jiahua Xie \\ Department of Pharmaceutical Sciences, Biomanufacturing Research Institute and Technology Enterprise, North Carolina Central University, Durham, NC 27707}

Additional index words. 'Florida Beauty', dracaena micropropagation, gold dust dracaena, ornamental foliage plants, spotted dracaena

\begin{abstract}
This study established a method of regenerating Dracaena surculosa Lindl. 'Florida Beauty' through indirect shoot organogenesis. Bud, leaf, and stem explants were cultured on a Murashige and Skoog basal medium supplemented with $\mathbf{N}_{6}$-(2-isopentyl) adenine (2iP) at 12.3 and $24.6 \mu \mathrm{M}$ with 3 -indoleacetic acid (IAA) at $0,1.1$, and $2.3 \mu \mathrm{M}$, respectively, and $2 \mathrm{iP}$ at $36.9,49.2,61.5$, and $73.8 \mu \mathrm{M}$ with IAA at 1.1 and $2.3 \mu \mathrm{M}$, respectively. Calluses were induced from leaf explants but failed to produce adventitious shoots. Calluses were also induced from stem and bud explants cultured on the basal medium containing 12.3 $\mu \mathrm{M} 2 \mathrm{iP}$ and $2.3 \mu \mathrm{M}$ IAA, 24.6 $\mu \mathrm{M} 2 \mathrm{iP}$ or higher with either 1.1 or $2.3 \mu \mathrm{M}$ IAA. The highest callus induction frequency was $63.2 \%$ from stem explants and $69.6 \%$ from bud explants when they were cultured on the basal medium supplemented with 49.2 $\mu$ M $2 \mathrm{iP}$ and $2.3 \mu \mathrm{M}$ IAA. The highest shoot formation frequency was $65.7 \%$ from stem-derived callus cultured on the basal medium containing $61.5 \mu \mathrm{M} 2 \mathrm{iP}$ and 1.1 $\mu \mathrm{M}$ IAA and $88 \%$ from bud-derived callus cultured with $49.2 \mu \mathrm{M} 2 \mathrm{iP}$ and 1.1 $\mu \mathrm{M}$ IAA. The highest number of shoots per piece of stem- and bud-derived calluses was 3.8 and 6.7, respectively. Adventitious shoots developed better root systems in the basal medium supplemented with $2.0 \mu$ M IAA. Plantlets after transplantation into a soilless substrate grew vigorously in a shaded greenhouse under a maximum photosynthetic photon flux density of $300 \mu \mathrm{mol} \cdot \mathrm{m}^{-2} \cdot \mathrm{s}^{-1}$. Neither disease incidence nor somaclonal variants were observed in the regenerated population. This established method could be used for efficient micropropagation of $D$. surculosa, and the availability of tissue-cultured liners could reduce the dependency on imported cuttings, which often bring new or invasive pests into the United States.
\end{abstract}

The genus Dracaena Vand. Ex L. encompasses 60 species of glabrous, herbaceous, woody shrubs or trees that are largely indigenous to tropical Africa and Asia (Hutchinson, 1986). As a result of their distinct foliage variegation and tolerance of low light levels, several species, including $D$. deremensis Engl., D. draco (L.) L., D. fragrans, (L.) KerGawl., D. marginata Lam., D. reflexa (Decne) Lam., D. sanderiana hort. Sander ex Mast., and D. surculosa Lindl., are important ornamental plants (Henny and Chen, 2003). Dracaenas rank second in Europe (Vonk Noordegraaf, 1998) and third in the United States (U.S. Department of Agriculture, 1999) as popular foliage plants used for interiorscaping. Dracaenas are also rich in

\footnotetext{
Received for publication 26 Apr. 2010. Accepted for publication 7 June 2010

${ }^{1}$ Current address: College of Horticulture, South China Agricultural University, Guangzhou, China. ${ }^{2}$ Current address: School of Ecological Technology and Engineering, Shanghai Institute of Technology, Shanghai, China.

${ }^{3}$ To whom reprint requests should be addressed; e-mail jjchen@ufl.edu.
}

steroidal sapogenins and saponins (Mimaki et al., 1998, 1999; Yokoduk et al., 2000), some of which have cytotoxic activities against cultural tumor cells (Mimaki et al., 1999), making them an important group of plants for pharmacognosy research.

Dracaenas as ornamental plants are propagated through cuttings, which are predominantly imported from Central America. Imported cuttings may carry and spread pathogens and pests (Palm and Rossman, 2003; Prado et al., 2008). For example, an invasive pathotype of Ralstonia solanacearum race 1 was identified from eye cuttings of golden pothos imported from Costa Rica to Florida (Norman and Yuen, 1998). In 2003, Childers and Rodrigues (2005) sampled 24 plant shipments, including cuttings of $D$. surculosa, entering the United States from Costa Rica, Honduras, and Guatemala and found half of the shipments infested with mites. A total of 81 mite species from 11 families was detected. The mites not only affect host plant growth, but also are vectors of viruses, including citrus leprosies virus, orchid fleck virus, and coffee ringspot virus (Miranda et al., 2007).
Micropropagation has become an important method of generating disease-free propagules of ornamental foliage plants (Chen and Henny, 2008). Reports of tissue culture of dracaenas date back to the 1970s when Miller and Murashige (1976) propagated D. surculosa using shoot tips. Subsequent studies included in vitro culture of axillary buds of $D$. deremensis (Badawy et al., 2005; Blanco et al., 2004; Debergh, 1976) and D. fragrans (Deberghs, 1975, 1976; Debergh and Maene, 1981) and regeneration of stem explants of $D$. marginata (Chua et al., 1981) and $D$. fragrans (Lu, 2003; Vinterhalter and Vinterhalter, 1997; Vinterhalter, 1989). However, in commercial practice, dracaena propagation has still relied on imported cuttings.

The use of cuttings may be justifiable if cane or stem length is an important component of the aesthetic value of finished plants such as $D$. fragrans and $D$. marginata. However, if plants are prized largely for their attractive foliage such as D. draco, D. surculosa, D. derenmesis, and D. sanderiana, micropropagated liners offer a better alternative to imported cuttings. However, micropropagation of dracaenas has been hampered by low multiplication rates and high occurrence of somaclonal variation. The numbers of shoot tips or axillary buds are often limited in dracaenas, and their use as explants produced limited numbers of shoots (Miller and Murashige, 1976). The occurrence of somaclonal variants or off types was high if plantlets were regenerated from variegated cultivars through indirect shoot organogenesis (Debergh, 1975; Vinterhalter and Vinterhalter, 1997). Thus far, a method for regenerating genetically stable plants from variegated dracaenas has not been well developed.

The objective of this study was to develop a reliable regeneration method for efficient propagation of genetically stable dracaenas using D. surculosa, commonly known as gold dust dracaena or spotted dracaena, as a model plant. Gold dust dracaena is a woody shrub, branching in an erect or arching habit. Leaves are elliptic, dark green, and variegated with irregular small, white or yellow round dots. In addition to the common steroidal saponins identified in dracaenas, four new 3,5cyclosteroidal saponins were recently found in this species (Yokoduk et al., 2002). The most popular cultivar of $D$. surculosa is Florida Beauty, which is widely used in dish gardens and terrariums as well as for landscape in tropical and subtropical regions. The establishment of a reliable regeneration method for its propagation could reduce importation of cuttings and also provide uniform raw materials for future pharmaceutical compound extraction (Rout et al., 2000).

\section{Materials and Methods}

Plant materials. Newly sprouted, tender shoots (6 to $8 \mathrm{~cm}$ long) with leaves as well as mature stems (the fifth node down, 4 to $5 \mathrm{~cm}$ long) with lateral buds were collected from D. surculosa 'Florida Beauty' stock plants in 
late spring. The stock plants had grown in a shaded greenhouse for 3 years under a maximum photosynthetic photon flux $(P P F)$ density of $300 \mu \mathrm{mol} \cdot \mathrm{m}^{-2} \cdot \mathrm{s}^{-1}$ at the University of Florida's Mid-Florida Research and Education Center in Apopka, FL. The tender shoots and mature stems were washed with running tap water for 15 min. Leaves were excised from the tender shoots. Leaves along with tender and mature stems were surface-sterilized by immersing them into a $70 \%$ ethanol solution for $1 \mathrm{~min}$ and soaking in a $20 \%$ Clorox $(1.2 \% \mathrm{NaOCl}$; Clorox Co., Oakland, CA) solution with a few drops of Tween-20 for $25 \mathrm{~min}$ with occasional agitation. After rinsing four to five times with sterile distilled water, leaf explants were obtained by cutting leaves, with the midvein in the center, into 1.44 to $2.25 \mathrm{~cm}^{2}$. Stem explants were produced by cutting the tender stems into $\approx 1-\mathrm{cm}$ long segments without nodes, and nodal explants were cut from the mature stems in $\approx 1.5$-cm lengths, each with a lateral bud.

Medium preparation. The basal medium consisted of Murashige and Skoog (Murashige and Skoog, 1962) mineral salts and vitamins, $3.0 \%(\mathrm{w} / \mathrm{v})$ sucrose, and $0.65 \%(\mathrm{w} / \mathrm{v})$ agar (Sigma, St. Louis, MO). Medium $\mathrm{pH}$ was adjusted to 5.8 with $1 \mathrm{M} \mathrm{KOH}$ before autoclaving at $12{ }^{\circ} \mathrm{C}$ for $25 \mathrm{~min}$. The plant growth regulator solutions of 6-benzyladenine (BA), $\mathrm{N}_{6}$-(2-isopentyl) adenine (2iP), 3-indoleacetic acid (IAA), $\alpha$-naphthalene acetic acid (NAA), N-phenyl-N'-1,2,3-thiadiazol-5-ylurea (TDZ), kinetin, or 3-indolebutyric acid were filtersterilized and added to the autoclaved basal medium when the medium temperature dropped to $\approx 50{ }^{\circ} \mathrm{C}$. The medium was aliquoted to petri dishes (Fisher Scientific Inc., Pittsburgh, PA) at $\approx 20 \mathrm{~mL}$ per dish.

Callus induction. To test the effects of growth regulator combinations on callus induction, a preliminary study was conducted by culturing bud, leaf, and stem explants on the basal medium supplemented with 4.4, 13.3, and $22.2 \mu \mathrm{M} \mathrm{BA} ; 4.5,13.6$, and 22.7 $\mu \mathrm{M}$ TDZ; 4.6, 13.9, and $23.2 \mu \mathrm{M}$ kinetin; or $4.9,12.3$, and $24.6 \mu \mathrm{M} 2 \mathrm{iP}$ with $0,0.6,1.4$, and $2.9 \mu \mathrm{M}$ IAA in a factorial combination. Buds were obtained by excising sprouted lateral buds, which were swollen and not open $(\approx 1 \mathrm{~cm})$, from the nodal explants cultured on the basal medium devoid of growth regulators for 3 weeks. Bud explants were placed vertically, leaf explants were placed with the adaxial surface up, and stem segments were placed horizontally. Petri dishes were sealed with parafilm $M$ (Fisher Scientific, Inc.). There were six explants per petri dish and five petri dishes per treatment. Based on the results of the preliminary test, subsequent experiments were carried out by culture of bud, leaf, and stem explants on the basal medium supplemented with $2 \mathrm{iP}$ at 12.3 and $24.6 \mu \mathrm{M}$ with IAA at $0,1.1$, and $2.3 \mu \mathrm{M}$, respectively, and $2 \mathrm{iP}$ at $36.9,49.2,61.5$, and $73.8 \mu \mathrm{M}$ with IAA at 1.1 and $2.3 \mu \mathrm{M}$, respectively. There were six explants per petri dish and 10 petri dishes per treatment.

Shoot induction. Calluses induced by different concentrations of $2 \mathrm{iP}$ and IAA were cut into $\approx 1-\mathrm{cm}^{3}$ pieces $(\approx 160 \mathrm{mg}$ in fresh weight) and cultured on the basal medium containing the same concentrations of $2 \mathrm{iP}$ and IAA as they were initially cultured for shoot induction. There were four callus pieces per petri dish and five dishes per treatment.

Culture conditions. The culture of bud, leaf, and stem explants in callus and shoot induction as well as the rooting of adventitious shoots took place in a culture room under a 12-h photoperiod provided by coolwhite fluorescent lamps with a photon flux density of $50 \mu \mathrm{mol} \cdot \mathrm{m}^{-2} \cdot \mathrm{s}^{-1}$ and temperature of $25 \pm 2{ }^{\circ} \mathrm{C}$.

Histological observation. Explants with calluses or calluses with shoots at different stages were taken weekly and fixed in FAA solution (formalin:glacial acetic acid: $70 \%$ ethanol at 5:5:90 by volume). After dehydration through an alcohol-xylol series, the samples were embedded in Paraplast with a 56 to $58^{\circ} \mathrm{C}$ melting point. The sections 7 to $8 \mu \mathrm{m}$ thick were stained with either Safranin-Fast green or Heidenhain's iron-alumhematoxylin and mounted on Permount ${ }^{\circledR}$ (Fisher Scientific). All the sections were observed under a Nikon OPTIPHOT microscope (Nikon Nippon Kogaku K.K., Tokyo, Japan) and photographed using a Canon S3 IS digital camera (Cannon U.S.A., Inc., Lake Success, NY).

Data collection and analysis. A completely random design was used for the induction of calluses and adventitious shoots. Each petri dish was considered an experimental unit. Explants or calluses that responded to the induction were recorded per petri dish weekly from 4 to 10 weeks after culture initiation. The frequencies of explants with callus formation and calluses with shoots as well as mean numbers of shoots per callus piece were calculated from data collected 10 weeks after culture. After checking normal distribution, data were analyzed by analysis of variance (SAS GLM; SAS Institute, Cary, $\mathrm{NC}$ ), and mean separations were determined using Fisher's protected least significant differences at the $5 \%$ levels.

Root development and ex vitro plantlet establishment. Adventitious shoots $(\approx 2$ to 3 $\mathrm{cm}$ in height) were exercised and transferred to baby food jars containing $25 \mathrm{~mL}$ of basal medium supplemented with 0.53 or $2.0 \mu \mathrm{M}$ IAA or $0.57 \mu \mathrm{M}$ NAA for root development. Well-rooted shoots were separated, washed free of agar using tap water, and transplanted individually in $10-\mathrm{cm}$ diameter pots containing a sphagnum peat-based substrate with Canadian peat, vermiculite, and perlite in $3: 1: 1$ ratio. All plantlets were maintained in the shaded greenhouse under a maximum $P P F$ density of $300 \mu \mathrm{mol} \cdot \mathrm{m}^{-2} \cdot \mathrm{s}^{-1}$, a temperature range of 20 to $28{ }^{\circ} \mathrm{C}$, and relative humidity of $70 \%$ to $100 \%$. Survival rates of plantlets in the shaded greenhouse were recorded 3 months after transplanting.

Morphological evaluation of regenerated plants. Seven months after the regenerated plants were grown in the shaded greenhouse, plant morphology was visually evaluated. The degree of leaf variegation was determined by collecting three mature leaves from
10 randomly selected regenerated plants and also from the stock plants using the quantification of leaf variegation method (Li et al., 2007). Briefly, the collected leaves were individually scanned, and the image of each variegated leaf was saved to a computer file. Total pixels of the entire leaf area and the total pixels of each color within the leaf were determined through Adobe Photoshop (Adobe Systems, San Jose, CA). The percentage of each color's total pixel count in relation to the total pixel count of the entire leaf was obtained. Total leaf area was measured by an LI-3100 area meter (LI-COR Biosciences, Lincoln, NE); the exact area of each color was calculated in reference to the pixel percentage obtained from the Photoshop program.

\section{Results}

Preliminary test. Bud, leaf, and stem explants cultured on the basal medium containing BA and IAA, TDZ and IAA, or kinetin and IAA, regardless of concentrations, had poor responses to the induction. Few explants produced calluses, some produced adventitious roots, and the others either died or showed no response. No adventitious shoots were produced from calluses after being subcultured on the same fresh medium. However, the explants cultured on the basal medium supplemented with $2 \mathrm{iP}$ and IAA produced calluses, and some calluses even produced adventitious shoots. The subsequent study thus focused on different concentrations of $2 \mathrm{iP}$ and IAA for the induction of calluses and shoots.

Callus induction. Leaf explants produced green-yellowish, fragile granular calluses at the cut edges, particularly around the midrib (Fig. 1A), when cultured on the basal medium supplemented with $2 \mathrm{iP}$ at $24.6 \mu \mathrm{M}$ or higher with IAA at 1.1 or $2.3 \mu \mathrm{M}$. However, the calluses turned brown and then dark and failed to produce adventitious shoots regardless of being maintained on the same medium or subcultured on the same fresh medium.

Cut ends of stem explants swelled after 4 weeks of culture on the basal medium supplemented with $12.3 \mu \mathrm{M} 2 \mathrm{iP}$ and $2.3 \mu \mathrm{M}$ IAA, $24.6 \mu \mathrm{M} 2 \mathrm{iP}$ or higher with either 1.1 or $2.3 \mu \mathrm{M}$ IAA (Table 1). Yellowish green calluses appeared from the cut ends with rapid expansion 2 weeks later (Fig. 1B). Callus proliferation produced an abundant callus mass. Stem explants cultured on the basal medium supplemented with $2 \mathrm{iP}$ at 49.2 $\mu \mathrm{M}$ and IAA at $2.3 \mu \mathrm{M}$ or $2 \mathrm{iP}$ at 61.5 with IAA at 1.1 or $2.3 \mu \mathrm{M}$ had the highest callus formation frequencies, $63.2 \%, 61.7 \%$, and $58.1 \%$, respectively (Table 1 ), followed by frequencies of $42.4 \%$ to $50.3 \%$ when cultured with $2 \mathrm{iP}$ at $73.8 \mu \mathrm{M}$ with IAA at 1.1 or 2.3 $\mu \mathrm{M}$ or $2 \mathrm{iP}$ at $49.2 \mu \mathrm{M}$ with IAA at $1.1 \mu \mathrm{M}$. Callus formation frequencies of the stem explants cultured with the other concentrations of $2 \mathrm{iP}$ and IAA were $33.2 \%$ or lower. There was no callus formation when stem explants were cultured with 2iP only or 12.3 $\mu \mathrm{M} 2 \mathrm{iP}$ with $1.1 \mu \mathrm{M}$ IAA. 

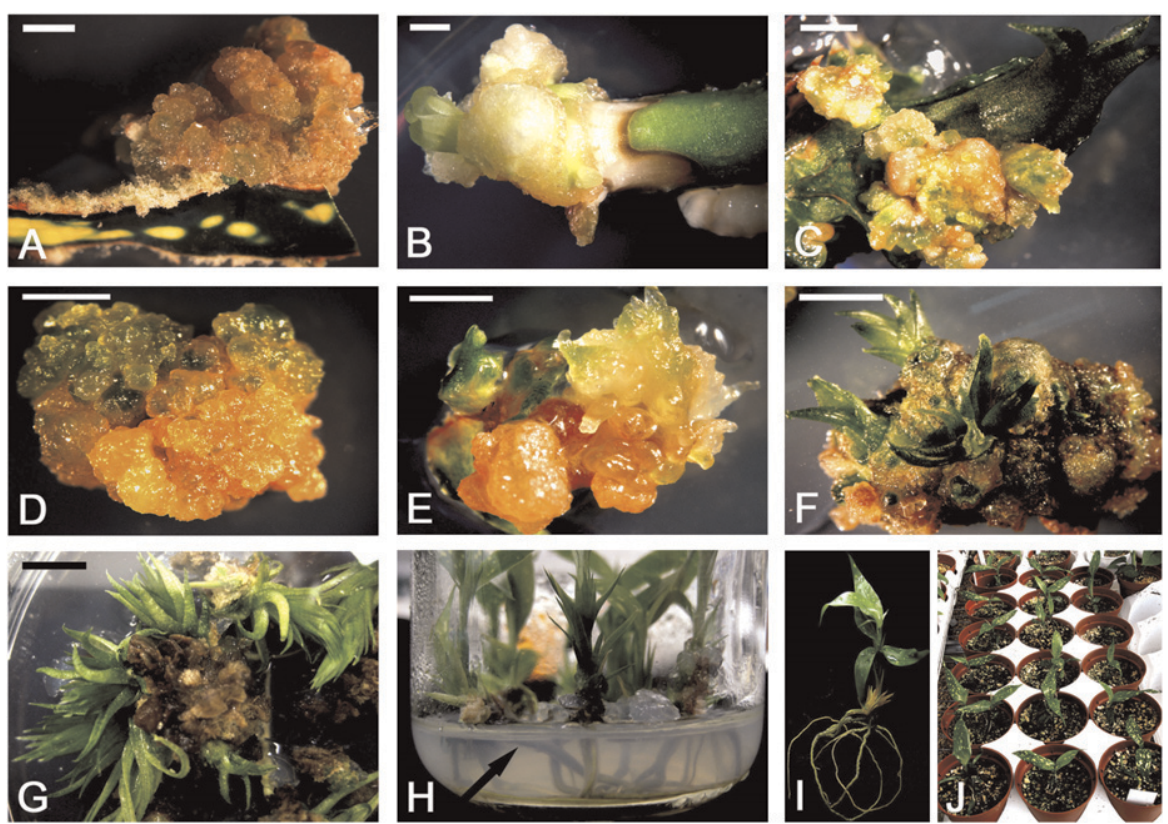

Fig. 1. Regeneration of Dracaena surculosa 'Florida Beauty' through indirect shoot organogenesis. (A) Callus formation from a leaf explant. (B) Callus occurrence at the cut end of a stem explant. (C) Callus appearance from the surface of a bud explant base, but the bud itself had shrunk. (D) Callus rapid proliferation. (E) Differentiation of callus produced bud primordia. (F) Adventitious shoots were formed from a callus mass. (G) Multiple adventitious shoots were produced from callus. (H) Adventitious shoots rooted in rooting medium in a baby food jar. (I) Plantlets with well-developed multiple roots. (J) Regenerated plants grown in a soilless substrate with spotted yellowish variegation in a shaded greenhouse. All bars $=1 \mathrm{~mm}$ except for the one in $\mathbf{G}$ that is $1 \mathrm{~cm}$.

Table 1. Frequency of callus formation from stem and bud explants after 10-week culture on a Murashige and Skoog basal medium supplemented with different concentrations of 2iP and IAA. ${ }^{2}$

\begin{tabular}{lccc}
\hline \multicolumn{2}{c}{ Growth regulator $^{\mathrm{y}}(\mu \mathrm{M})$} & & Bud explant $(\%)$ \\
\hline $2 \mathrm{iP}$ & IAA & Stem explant $(\%)$ & $0 \pm 0.0$ \\
\hline 12.3 & 0 & $0 \pm 0.0$ & $0 \pm 0.0$ \\
& 1.1 & $0 \pm 0.0$ & $10.2 \pm 0.0 \mathrm{e}$ \\
24.6 & 2.3 & $5.3 \pm 0.9 \mathrm{f}$ & $0 \pm 0.0$ \\
& 0 & $0 \pm 0.0$ & $24.7 \pm 2.1 \mathrm{de}$ \\
36.9 & 1.1 & $19.1 \pm 1.8 \mathrm{e}$ & $32.9 \pm 3.2 \mathrm{~d}$ \\
& 2.3 & $28.6 \pm 2.1 \mathrm{~d}$ & $44.4 \pm 2.8 \mathrm{c}$ \\
49.2 & 1.1 & $33.2 \pm 2.7 \mathrm{~d}$ & $56.9 \pm 2.1 \mathrm{~b}$ \\
& 2.3 & $31.2 \pm 3.1 \mathrm{~d}$ & $61.0 \pm 3.7 \mathrm{~b}$ \\
61.5 & 1.1 & $48.5 \pm 2.7 \mathrm{~b}$ & $69.6 \pm 3.3 \mathrm{a}$ \\
& 2.3 & $63.2 \pm 2.4 \mathrm{a}$ & $60.7 \pm 3.1 \mathrm{~b}$ \\
73.8 & 1.1 & $61.7 \pm 2.1 \mathrm{a}$ & $52.1 \pm 2.3 \mathrm{bc}$ \\
& 2.3 & $58.1 \pm 2.6 \mathrm{ab}$ & $33.7 \pm 2.7 \mathrm{~d}$ \\
& 1.1 & $42.4 \pm 2.1 \mathrm{c}$ & $39.2 \pm 2.1 \mathrm{~cd}$ \\
\hline
\end{tabular}

${ }^{\mathrm{z}}$ Six explants per petri dish and 10 petri dishes per treatment.

${ }^{\mathrm{y}}$ Basal medium comprised of Murashige and Skoog mineral salts and vitamins, 3.0\% (w/v) sucrose, and $0.65 \%(\mathrm{w} / \mathrm{v})$ agar, of which $2 \mathrm{iP}=\mathrm{N}_{6}-(2$-isopentyl) adenine and IAA $=3$-indoleacetic acid.

xDifferent letters within a column represent significant difference at $P \leq 0.5$ by Fisher's protected least significant difference test.

Small green-yellowish calluses were observed after 3 to 4 weeks at the base of bud explants cultured on the basal medium supplemented with $2 \mathrm{iP}$ at $12.3 \mu \mathrm{M}$ with IAA at $2.3 \mu \mathrm{M}$ or $2 \mathrm{iP}$ at $24.6 \mu \mathrm{M}$ or higher with IAA at either 1.1 or $2.3 \mu \mathrm{M}$. The multiplication of calluses resulted in the shrinkage (Fig. 1C) and eventually the death of bud explants. Calluses derived from bud explants were similar to those produced from stem explants: solid and nodular with rapid proliferation (Fig. 1D). The highest callus formation frequency $(69.6 \%)$ occurred in bud explants cultured on the basal medium supplemented with $2 \mathrm{iP}$ at
$49.2 \mu \mathrm{M}$ and IAA at $2.3 \mu \mathrm{M}$ followed by frequencies of $52.1 \%$ to $61.0 \%$ when bud explants were cultured with $2 \mathrm{iP}$ at $61.5 \mu \mathrm{M}$ with IAA at 1.1 or $2.3 \mu \mathrm{M}, 2 \mathrm{iP}$ at $36.9 \mu \mathrm{M}$ with IAA at $2.3 \mu \mathrm{M}$, or $2 \mathrm{iP}$ at $49.2 \mu \mathrm{M}$ with IAA at $1.1 \mu \mathrm{M}$ (Table 1). Callus formation frequencies were $44.4 \%$ or lower when bud explants were cultured using the other concentrations of $2 \mathrm{iP}$ and IAA. Calluses were also not formed from bud explants cultured on the basal medium supplemented with $2 \mathrm{iP}$ only or $2 \mathrm{iP}$ at $12.3 \mu \mathrm{M}$ with IAA at $1.1 \mu \mathrm{M}$.

Shoot induction. Regardless of their origins (stem or bud explants), calluses cultured on the basal medium supplemented with $2 \mathrm{iP}$ at $24.6 \mu \mathrm{M}$ or higher with IAA at either 1.1 or $2.3 \mu \mathrm{M}$ differentiated and produced bud primordia (Fig. 1E) and adventitious shoots (Fig. 1F-G). The highest frequency in shoot formation was $65.7 \%$ from stem-derived calluses cultured with $2 \mathrm{iP}$ at $61.5 \mu \mathrm{M}$ and IAA at $1.1 \mu \mathrm{M}$ (Table 2) followed by $57.8 \%$ and $48.3 \%$ for the calluses cultured with 49.2 $\mu \mathrm{M} 2 \mathrm{iP}$ with $1.1 \mu \mathrm{M}$ and $61.5 \mu \mathrm{M} 2 \mathrm{iP}$ with $2.3 \mu \mathrm{M}$ IAA, respectively. Shoot formation frequencies for stem-derived calluses cultured with the other concentrations of $2 \mathrm{iP}$ and IAA were $42.1 \%$ or lower. The number of shoots per callus piece ranged from 1.2 to 3.8 (Table 2) with the highest in calluses cultured with $49.2 \mu \mathrm{M} 2 \mathrm{iP}$ and $1.1 \mu \mathrm{M}$ IAA.

The highest shoot formation frequency for calluses derived from bud explants was $88 \%$ when cultured with $49.2 \mu \mathrm{M} 2 \mathrm{iP}$ and $1.1 \mu \mathrm{M}$ IAA (Table 2). Shoot formation frequencies decreased to $67.3 \%$ when cultured with 49.2 $\mu \mathrm{M} 2 \mathrm{iP}$ and $2.3 \mu \mathrm{M}$ IAA and $59.8 \%$ and $55.5 \%$ when cultured with $36.9 \mu \mathrm{M} 2 \mathrm{iP}$ with 1.1 and $2.3 \mu \mathrm{M}$ IAA, respectively. Other concentrations of $2 \mathrm{iP}$ and IAA, including $61.5 \mu \mathrm{M} 2 \mathrm{iP}$ and $1.1 \mu \mathrm{M}$ IAA that induced the highest shoot formation frequency for the stem-derived callus, had shoot formation frequencies of $46.1 \%$. The highest mean number of shoots per callus piece was 6.7, which happened in calluses cultured with $49.2 \mu \mathrm{M} 2 \mathrm{iP}$ and $1.1 \mu \mathrm{M}$ IAA as well. It became apparent that bud-derived calluses generally had higher shoot formation frequencies and higher numbers of shoots than stem-derived calluses. The concentration of 2iP used for inducing the highest shoot formation frequency was lower for bud-derived calluses $(49.2 \mu \mathrm{M})$ than stem-derived calluses $(61.5 \mu \mathrm{M})$.

Histological analysis. The section analysis indicated that shoot meristem appeared from the callus mass, and there was a vascular connection between explant and callusderived bud primordia (Fig. 2A). The development of bud primordia produced shoot apical structure with young leaves (Fig. 2B). Later the shoot elongated with shoot meristem and multiple young leaves (Fig. 2C).

Rooting and acclimatization. Approximately $40 \%$ of the adventitious shoots spontaneously produced roots on the shoot induction medium (data not shown). However, better rooting $(100 \%)$ occurred after shoots were cultured on the basal medium supplemented with 0.53 or $2.0 \mu \mathrm{M}$ IAA or $0.57 \mu \mathrm{M}$ NAA, particularly with $2.0 \mu \mathrm{M}$ IAA (Fig. $1 \mathrm{H}$ ) in which multiple roots were produced (Fig. 1I). After transplanting, the regenerated plants grew vigorously in the soilless substrate (Fig. 1J). A total of 700 plantlets was transplanted and their survival rate in the shaded greenhouse was $100 \%$.

Morphological evaluation. All regenerated plants were variegated and resembled the original stock plants. The mean leaf area of mature leaves of the regenerated plants ranged from 36.4 to $40.7 \mathrm{~cm}^{2}$ compared with 35.8 to $41.2 \mathrm{~cm}^{2}$ for the leaves sampled from the stock plants. The total variegated area 
Table 2. Frequency of adventitious shoot formation from stem- and bud-derived calluses and mean shoot numbers per callus piece after 10-week culture on a Murashige and Skoog basal medium supplemented with different concentrations of $2 \mathrm{iP}$ and IAA. ${ }^{\mathrm{z}}$

\begin{tabular}{|c|c|c|c|c|c|}
\hline \multirow{2}{*}{\multicolumn{2}{|c|}{ Growth regulator ${ }^{\mathrm{y}}(\mu \mathrm{M})$}} & \multicolumn{2}{|c|}{ Callus initially from stem explant } & \multicolumn{2}{|c|}{ Callus initially from bud explant (\%) } \\
\hline & & \multirow{2}{*}{$\begin{array}{l}\text { Callus with } \\
\text { shoots }(\%)\end{array}$} & \multirow{2}{*}{$\begin{array}{l}\text { Shoot numbers per } \\
\text { callus piece }\end{array}$} & \multirow{2}{*}{$\begin{array}{l}\text { Callus with } \\
\text { shoots }(\%)\end{array}$} & \multirow{2}{*}{$\begin{array}{l}\text { Shoot numbers per } \\
\text { callus piece }\end{array}$} \\
\hline$\overline{2 \mathrm{iP}}$ & IAA & & & & \\
\hline \multirow[t]{2}{*}{$\overline{24.6}$} & 1.1 & $8.6 \pm 1.1 \mathrm{f}^{\mathrm{x}}$ & $1.2 \pm 0.2 \mathrm{~b}$ & $17.5 \pm 1.7 \mathrm{~g}$ & $1.5 \pm 0.3 \mathrm{f}$ \\
\hline & 2.3 & $10.9 \pm 1.7 \mathrm{f}$ & $1.4 \pm 0.1 \mathrm{~b}$ & $27.8 \pm 2.1 \mathrm{f}$ & $2.1 \pm 0.4 \mathrm{e}$ \\
\hline \multirow[t]{2}{*}{36.9} & 1.1 & $27.8 \pm 2.5 \mathrm{e}$ & $2.1 \pm 0.2 \mathrm{~b}$ & $59.9 \pm 2.4 \mathrm{c}$ & $2.9 \pm 0.4 \mathrm{~d}$ \\
\hline & 2.3 & $36.5 \pm 2.1 \mathrm{~d}$ & $1.9 \pm 0.2 \mathrm{~b}$ & $55.5 \pm 2.8 \mathrm{c}$ & $4.1 \pm 0.7 b$ \\
\hline \multirow[t]{2}{*}{49.2} & 1.1 & $57.8 \pm 2.7 b$ & $3.8 \pm 0.3 \mathrm{a}$ & $88.0 \pm 3.3 \mathrm{a}$ & $6.7 \pm 0.9 \mathrm{a}$ \\
\hline & 2.3 & $42.1 \pm 2.7 \mathrm{~cd}$ & $3.2 \pm 0.3 \mathrm{a}$ & $67.3 \pm 3.1 b$ & $4.6 \pm 0.7 b$ \\
\hline \multirow[t]{2}{*}{61.5} & 1.1 & $65.7 \pm 3.1 \mathrm{a}$ & $3.7 \pm 0.2 \mathrm{a}$ & $46.1 \pm 1.8 \mathrm{~d}$ & $3.7 \pm 0.6 \mathrm{c}$ \\
\hline & 2.3 & $48.3 \pm 2.3 \mathrm{c}$ & $3.5 \pm 0.2 \mathrm{a}$ & $37.5 \pm 2.6 \mathrm{e}$ & $2.2 \pm 0.4 \mathrm{e}$ \\
\hline \multirow[t]{2}{*}{73.8} & 1.1 & $34.2 \pm 2.7 \mathrm{~d}$ & $2.0 \pm 0.2 \mathrm{~b}$ & $22.3 \pm 1.3 \mathrm{fg}$ & $0.7 \pm 0.2 \mathrm{f}$ \\
\hline & 2.3 & $37.0 \pm 2.3 \mathrm{~d}$ & $1.7 \pm 0.1 \mathrm{~b}$ & $27.5 \pm 2.1 \mathrm{f}$ & $1.1 \pm 0.3 \mathrm{f}$ \\
\hline
\end{tabular}

${ }^{\mathrm{z}}$ Four callus pieces per petri dish and five petri dishes per treatment.

${ }^{\mathrm{y}}$ Basal medium comprised of Murashige and Skoog mineral salts and vitamins, 3.0\% (w/v) sucrose, and $0.65 \%(\mathrm{w} / \mathrm{v})$ agar, of which $2 \mathrm{iP}=\mathrm{N}_{6}$-(2-isopentyl) adenine and IAA $=3$-indoleacetic acid.

'Different letters within a column represent significant difference at $P \leq 0.5$ by Fisher's protected least significant difference test.
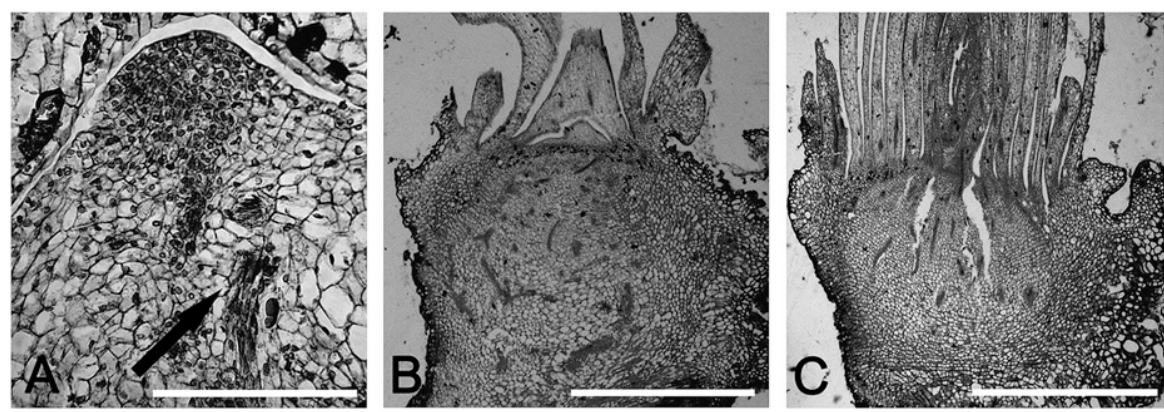

Fig. 2. Longitudinal sections of indirect shoot organogenesis from a stem explant of Dracaena surculosa 'Florida Beauty'. (A) A shoot apical dome was formed from callus with vascular connection to stem explant (pointed by an arrow). (B) Differentiation of apical meristem led to appearance of young leaves. (C) Further differentiation produced multiple young leaves. Bars $=1 \mathrm{~mm}$.

(yellowish white dots) per leaf for the regenerated plants varied from 18.1 to $21.5 \mathrm{~cm}^{2}$ compared with 17.9 to $22.3 \mathrm{~cm}^{2}$ for the leaves sampled from the stock plants. The mean percentage of variegation for regenerated plants was $51.3 \%$ compared with $52.0 \%$ of the stock plants.

\section{Discussion}

Regeneration protocol. This study established a new method of regenerating $D$. surculosa 'Florida Beauty'. Both stem and bud explants can be cultured on the basal medium supplemented with $49.2 \mu \mathrm{M} 2 \mathrm{iP}$ and $2.3 \mu \mathrm{M}$ IAA for callus induction. Calluses derived from stem explants should be cultured on the basal medium containing $61.5 \mu \mathrm{M} 2 \mathrm{iP}$ and $1.1 \mu \mathrm{M}$ IAA and calluses produced from bud explants should be cultured with $49.2 \mu \mathrm{M}$ $2 \mathrm{iP}$ and $1.1 \mu \mathrm{M}$ IAA for shoot induction. Adventitious shoots will root better in the basal medium supplemented with $2.0 \mu \mathrm{M}$ IAA. Rooted plantlets can be transplanted in a commercial soilless substrate with Canadian peat, vermiculite, and perlite in a 3:1:1 ratio and grown in a shaded greenhouse under a maximum $P P F$ density of $300 \mu \mathrm{mol} \cdot \mathrm{m}^{-2} \cdot \mathrm{s}^{-1}$, temperature range of 20 to $28^{\circ} \mathrm{C}$, and relative humidity of $70 \%$ to $100 \%$.
This established protocol is different from the other reported micropropagation methods for dracaenas. Adventitious shoots were regenerated through indirect shoot organogenesis (Figs. 1 and 2) from both stem and bud explants using 2iP and IAA only. All previous reports used explants with pre-existing meristems such as shoots or nodes, which were cultured with cytokinins other than $2 \mathrm{iP}$. For example, plantlets were produced from shoot culture of $D$. deremensis, $D$. fragrans, and $D$. surculosa on media containing kinetin and naphtoxyacetic acid (Debergh, 1975, 1976), kinetin and IAA (Badawy et al., 2005; Blanco et al., 2004; Miller and Murashige, 1976), or calluses were induced from shoot or nodal explants of $D$. deremensis, $D$. fragrans, $D$. marginata, and D. sanderiana by $2,4-\mathrm{D}$ only (Chua et al., 1981; Junaid et al., 2008; Vinterhalter, 1989) or 2,4-D with BA (Lu, 2003) and shoots were induced using BA or kinetin only or BA with NAA.

The present study also showed that regeneration failed to occur in both stem and bud explants of D. surculosa 'Florida Beauty' cultured on the basal medium containing BA and IAA, TDZ and IAA, or kinetin and IAA. The failure could be that $2 \mathrm{iP}$, as a naturally occurring cytokinin, is more effective than those synthetic counter- parts such as BA, TDZ, and kinetin in induction of morphogenesis of $D$. surculosa 'Florida Beauty'. The endogenous 2iP in explants might interfere with the action of the synthetic cytokinins. In general, root tips are the major site of natural cytokinin biosynthesis, but other actively growing tissues such as apical buds also synthesize cytokinins (Chen et al., 1985). The requirement of a higher concentration of $2 \mathrm{iP}$ and lower concentration of IAA for shoot induction from stem-derived calluses may suggest that bud explants had a relatively higher concentration of endogenous 2iP. It is possible that $2 \mathrm{iP}$ is better suited for inducing morphogenesis of D. surculosa, probably monocots in general because $2 \mathrm{iP}$ was successfully used to induce shoot formation of Asparagus plumosus (Fonnesbech et al., 1979), Dieffenbachia (Shen et al., 2007; Voyiatzi and Voyiatzis, 1989), Epipremnum aureum (Qu et al., 2002), and Syngonium (Cui et al., 2008); all are monocots.

Morphological stability among regenerated plants. Another distinction of this established method is that the regenerated plants were morphologically stable. As early as the 1970s, Debergh $(1975,1976)$ found that $90 \%$ of plantlets micropropagated from $D$. deremensis through shoot culture had 10\% off types. On the other hand, if plantlets were regenerated from indirect shoot organogenesis, all plantlets lost their variegation pattern. Regeneration of D. marginata 'Tricolor' through the callus phase resulted in all regenerated plants losing the creamish white stripe (Chua et al., 1981). The highly variable phenotypes among regenerated plants from the aforementioned variegated Dracaena species could be explained by the fact that their variegation belongs to the cell lineage type. Cell lineage variegation generally occurs in genetic mosaics, i.e., individuals with cells of different genotypes (Marcotrigiano, 1997). The most common cell lineage variegation patterns are formed by periclinal chimeras in which cell layers with different genotypes develop next to each other (Tilney-Basset, 1986). Depending on which cells or which group of cells redifferentiate to produce calluses and subsequently differentiate into shoots, regenerated plants may morphologically vary. Because plantlets with green leaves often are more competent than those variegated or completely yellowish ones, the percentage of green plantlets outperforms the variegated ones among the regenerate populations.

It is unknown why D. surculosa 'Florida Beauty' regenerated through indirect shoot organogenesis in this study were morphologically stable. A possibility could be that calluses had not been maintained in culture long enough for inducing variants, because somaclonal variation generally increases with the time that a culture has been maintained in vitro, especially for callus culture (Chen and Henny, 2006; Skirvin et al., 1994). However, our recent regenerated plants of 'Florida Beauty' from calluses that had been maintained in culture for 1 year were still 
morphologically stable. Another possibility could be that plants regenerated by naturally occurring $2 \mathrm{iP}$ are relatively stable compared with those obtained using synthetic forms.

Nevertheless, this study established an indirect shoot organogenesis method for regeneration of $D$. surculosa 'Florida Beauty'. Regenerated plants have been shown to be morphologically stable and disease-free. The use of this established method for micropropagation should reduce the reliance on imported cuttings and reduce the incidence of importing invasive pathogens and pests. Additionally, the established method provides an opportunity for potentially largescale production of steroidal sapogenins and saponins through bioreactors.

\section{Literature Cited}

Badawy, E.M., A.M.A. Habib, A. El-Bana, and G.M. Yosry. 2005. Propagation of Dracaena fragrans plants by tissue culture technique. Arab J. Biotechnol. 8:329-342.

Blanco, M., R. Valverde, and L. Gomez. 2004. Micropropagation of Dracaena deremensis. Agronomia Costarricense 28:7-15.

Chen, J. and R.J. Henny. 2006. Somaclonal variation: An important source for cultivar development of floriculture crops, p. 244-253. In: Teixeira da Silva, J.A. (ed.). Floriculture, ornamental and plant biotechnology, Volume II. Global Science Books, London, UK.

Chen, J. and R.J. Henny. 2008. Role of micropropagation in the development of ornamental foliage plant industry, p. 206-218. In: Teixeira da Silva, J.A. (ed.). Floriculture, ornamental and plant biotechnology, Volume V. Global Science Books, London, UK.

Chen, C.M., J.R. Ertl, S.M. Leisner, and C.C. Chang. 1985. Localization of cytokinin biosynthesis sites in pea plant and carrot roots. Plant Physiol. 78:510-513.

Childers, C.C. and J.C.V. Rodrigues. 2005. Potential pest mite species collected on ornamental plants from Central America at port of entry to the United States. Fla. Entomol. 88:408-414.

Chua, B.U., J.T. Kunisaki, and Y. Sagawa. 1981. In vitro propagation of Dracaena marginata 'Tricolor'. HortScience 16:494.

Cui, J., J. Liu, M. Deng, J. Chen, and R.J. Henny. 2008. Plant regeneration through protocormlike bodies induced from nodal explants of Syngonium podophyllum 'White Butterfly'. HortScience 43:2129-2133.

Debergh, P.C. 1975. Intensified vegetative multiplication of Dracaena deremensis. Acta Hort. 54:83-92.
Debergh, P.C. 1976. An in vitro technique for the vegetative multiplication of chimaeral plants of Dracaena and Cordyline. Acta Hort. 64: $17-19$.

Debergh, P.C. and L.J. Maene. 1981. A scheme for commercial propagation of ornamental plants by tissue culture. Sci. Hort. 14:335-345.

Fonnesbech, A., M. Fonnesbech, and N. Bredmose. 1979. Influence of cytokinins and temperature on development of Asparagus plumosus shoot tips in vitro. Physiol. Plant. 45:73-76.

Henny, R.J. and J. Chen. 2003. Cultivar development of ornamental foliage plants, p. 245-290. In: Janick, J. (ed.). Plant breeding reviews. Volume 23. John Wiley and Sons, Inc., Hoboken, NJ.

Hutchinson, J. 1986. Dracaenas in West Africa. Clarendon Press, Oxford, UK.

Junaid, A., A. Mujib, and M.P. Sharma. 2008. Effect of growth regulators and ethylmethane sulphonate on growth, and chlorophyll, sugar and proline contents in Dracaena sanderiana culture in vitro. Biol. Plant. 52:569-572.

Li, Q., J. Chen, D.B. McConnell, and R.J. Henny. 2007. A simple and effective method of quantifying leaf variegation. HortTechnology 17: 285-288.

Lu, W. 2003. Control of in vitro regeneration of individual reproductive and vegetative organs in Dracaena fragrans cv. Massangeana Hort.Regularities of the direct regeneration of individual organs in vitro. Acta Bot. Sin. 45: 1453-1464.

Marcotrigiano, M. 1997. Chimeras and variegation: Patterns of deceit. HortScience 32:773784.

Miller, R. and T. Murashige. 1976. Tissue culture propagation of tropical foliage plants. In Vitro $12: 797-813$

Mimaki, Y., M. Kuroda, A. Ide, A. Kameyama, A. Yokosuka, and Y. Sashida. 1999. Steroidal saponins from the aerial parts of Dracaena draco and their cytostatic activity on HL-60 cells. Phytochemistry 50:805-813.

Mimaki, Y., M. Kuroda, Y. Takaashi, and Y. Sashida. 1998. Steroidal saponins from the stems of Dracaena concinna. Phytochemistry 47:1351-1356.

Miranda, L.C., D. Návia, and J.C. Rodrigues. 2007. Brevipalpus mites Donnadieu (Prostigmata: Tenuipalpidae) associated with ornamental plants in Distrito Federal, Brazil. Neotrop. Entomol. 36:587-592.

Murashige, T. and F. Skoog. 1962. A revised medium for rapid growth and bioassays with tobacco tissue cultures. Physiol. Plant. 15:473-497.

Norman, D.J. and J.M.F. Yuen. 1998. A distinct pathotype of Ralstonia (Pseudomonas) solanacearum race 1, biovar 1 entering Florida in pothos (Epipremnum aureum) cuttings. Can. J. Plant Pathol. 20:171-175.

Palm, M.E. and A.Y. Rossman. 2003. Invasion pathways of terrestrial plant-inhabiting fungi, p. 31-43. In: Ruiz, G.M. and J.T. Carlton (eds.). Invasive species: Vectors and management strategies. Island Press, Washington, DC.

Prado, J., F. Casanoves, E. Hildago, T. Benjamin, and C. Sadof. 2008. Effects of production practices on the abundance of quarantine pests in Dracaena marginata in Costa Rican production fields. J. Econ. Entomol. 101:17791785.

Qu, L., J. Chen, R.J. Henny, Y. Huang, R.D. Caldwell, and C.A. Robinson. 2002. Adventitious shoot regeneration of pothos (Epipremnum aureum) using leaf explants. In Vitro Cell. Dev. Biol. Plant 38:268-271.

Rout, G.R., S. Samantaray, and P. Das. 2000. In vitro manipulation and propagation of medicinal plants. Biotechnol. Adv. 18:91120.

Shen, X., J. Chen, and M.E. Kane. 2007. Indirect shoot organogenesis from leaves of Dieffenbachia cv. Camouflage. Plant Cell Tiss. Org. Cult. 89:83-90.

Skirvin, R.M., K.D. McPheeters, and M. Norton. 1994. Sources and frequency of somaclonal variation. HortScience 29:1232-1236.

Tilney-Basset, R.A.E. 1986. Plant chimeras. Cambridge University Press, Cambridge, UK.

U.S. Department of Agriculture. 1999. 1998 census of horticultural specialties. USDA, Washington, DC.

Vinterhalter, D. and B. Vinterhalter. 1997. Micropropagation of Dracaena species, p. 131-146. In: Bajaj, Y.P.S. (ed.). Biotechnology in agriculture and forestry 40: High-tech and micropropagation VI. Springer-Verlag, Berlin, Germany.

Vinterhalter, D.V. 1989. In vitro propagation of green-foliaged Dracaena fragrans Ker. Plant Cell. Tiss. Org. Cult. 17:13-19.

Vonk Noordegraaf, C. 1998. Trends and requirements in floriculture in Europe. Acta Hort. 454:39-48.

Voyiatzi, C. and D.G. Voyiatzis. 1989. In vitro shoot proliferation rate of Dieffenbachia exotica cultivar 'Marianna' as affected by cytokinins, the number of recultures and the temperature. Sci. Hort. 40:163-169.

Yokoduk, A., Y. Mimaki, and Y. Sashida. 2000. Steroidal saponins from Dracaena surculosa. J. Nat. Prod. 63:1239-1243.

Yokoduk, A., Y. Mimaki, and Y. Sashida. 2002. Four new 3,5-cyclosteroidal saponins from Dracaena surculosa. Chem. Pharm. Bull. (Tokyo) 50:992-995. 